\title{
Post-transplant plasma cell myeloma and polymorphic lymphoproliferative disorder with monoclonal serum protein occurring in solid organ transplant recipients
}

\author{
Xiaoping Sun*, LoAnn C Peterson, Yun Gong ${ }^{\dagger}$, Ann E Traynor ${ }^{\ddagger}$ and Beverly P Nelson \\ Northwestern University Feinberg School of Medicine, Chicago, IL, USA
}

\begin{abstract}
Post-transplant lymphoproliferative disorders are mostly Epstein-Barr virus-related, B-cell tumors that develop as a consequence of immunosuppressive therapy in recipients of solid organ or bone marrow transplants. These disorders range from reactive, polyclonal plasmacytic hyperplasia to those that are morphologically and genotypically indistinguishable from typical non-Hodgkin's lymphomas. Plasma cell myeloma occurring after solid organ transplantation is rare. We report three plasma cell myeloma post-transplant lymphoproliferative disorder cases and one polymorphic, monoclonal post-transplant lymphoproliferative disorder case associated with a monoclonal serum protein. All three plasma cell myeloma post-transplant lymphoproliferative disorder cases had clinical, radiologic, and pathologic features of conventional plasma cell myeloma. The one polymorphic post-transplant lymphoproliferative disorder case was associated with an IgM monoclonal serum protein and was morphologically indistinguishable from a lymphoplasmacytic lymphoma. Three of the four cases, including the one polymorphic post-transplant lymphoproliferative disorder case, were positive for Epstein-Barr virus encoded small RNA by in situ hybridization. One patient died of plasma cell myeloma posttransplant lymphoproliferative disorder. The remaining three patients are alive: two are completely free of posttransplant lymphoproliferative disorder, and one has shown partial response to therapy. We compare the clinicopathologic features of these cases with those in the literature.
\end{abstract}

Modern Pathology (2004) 17, 389-394, advance online publication, 20 February 2004; doi:10.1038/modpathol.3800080

Keywords: PTLD; myeloma; solid organ transplantation

Post-transplant lymphoproliferative disorders (PTLD) are mostly Epstein-Barr virus (EBV)-related, B-cell tumors that develop as a consequence of immunosuppressive therapy in recipients of solid organ or bone marrow transplants. Approximately $15 \%$ of PTLD are EBV negative. ${ }^{1,2}$ The recipient's age, EBV seronegativity at transplant, and allograft

Correspondence: X Sun, MD, PhD, Department of Laboratory Medicine, Unit 37, Division of Pathology and Laboratory Medicine, The University of Texas MD Anderson Cancer Center, 1515 Holcombe Blvd., Houston, TX 77030, USA.

E-mail: xsun@mdanderson.org

${ }^{*}$ Current address: Department of Laboratory Medicine, Division of Pathology and Laboratory Medicine, The University of Texas MD Anderson Cancer Center, Houston, TX, USA

Current address: Department of Pathology, Division of Pathology and Laboratory Medicine, The University of Texas MD Anderson Cancer Center, Houston, TX, USA

${ }^{\ddagger}$ Current address: Division of Hematology/Oncology, Department of Medicine, The University of Massachusetts Memorial Medical Center, 55 Lake Avenue North, Worcester, MA, USA

Received 14 July 2003; revised and accepted 22 October 2003; published online 20 February 2004 type are recognized risk factors for PTLD. ${ }^{3-5}$ PTLD have a predilection for extranodal sites, similar to lymphomas that occur in other immunocompromised patients. ${ }^{6}$

The overall incidence of PTLD is about $1.5 \%$ in all solid organ transplant recipients ${ }^{7-10}$ and $1 \%$ in bone marrow transplant recipients. ${ }^{11}$ Of the solid organ transplant recipients, renal allograft recipients have the lowest frequency of PTLD $(<1 \%)$. Approximately $2-9 \%$ of cardiac allograft recipients, $5-9 \%$ of combined heart/lung recipients, ${ }^{12,13}$ and $2 \%$ of hepatic allograft recipients develop PTLD. ${ }^{14,15}$ The variable PTLD incidence among the organ recipients may reflect at least in part the degree of posttransplant immunosuppressive therapy, which is usually highest in recipients of heart, lung, or liver allografts.

PTLD include reactive, polyclonal plasmacytic hyperplasia as well as lesions that are morphologically and genotypically indistinguishable from typical non-Hodgkin's lymphomas. Monoclonal serum proteins, similar to those that are found in a 
subset of non-Hodgkin's lymphomas, occur 10 times more frequently in solid organ transplant recipients than in the general population. ${ }^{16}$ The majority of these monoclonal serum proteins are small, and not associated with lytic bone lesions or a discrete, localized proliferation of plasma cells. For instance, small $(<0.1 \mathrm{~g} / \mathrm{dl})$, transient monoclonal serum proteins are reported in $30 \%$ of renal allograft recipients without evidence of myeloma. Plasma cell myeloma occurring after solid organ transplantation with clinical and pathologic features as defined for the nontransplant setting is rare (estimated at less than $4 \%$ of all PTLD). ${ }^{17-21}$ Although most reported plasma cell myeloma PTLD cases have localized collections of plasma cells and bone marrow involvement, other clinical findings of typical plasma cell myeloma such as lytic bone lesions and hypercalcemia were frequently absent, and most were not tested for EBV. There are rare single case reports of plasma cell myeloma PTLD that meet the criteria for plasma cell myeloma as is defined in the nontransplant-related setting. ${ }^{20}$ Most other reported cases of plasma cell myeloma PTLD, do not make a clear distinction from reactive plasmacytic hyperplasia, monomorphic, or polymorphic PTLD with plasmacytic differentiation, lesions that may also have serum monoclonal proteins.

We report the pathologic and clinical findings in four solid organ transplant recipients who devel- oped post-transplant plasma cell myeloma (three cases) or polymorphic PTLD with a monoclonal serum protein (one case), and we review the reported cases in the literature.

\section{Case report}

\section{Case 1}

A 67-year-old man with hepatitis C-induced cirrhosis received a liver transplant in June 1994. Immunosuppressive therapy was cyclosporine (Table 1). At 2 years after receiving the transplant (May 1996), he presented with a pathologic fracture of the left femur in the sub-trochanteric region. $\mathrm{X}$-ray showed a lytic lesion at the fracture site and also in the right, inter-trochanteric region of the femur. Serum IgG kappa monoclonal protein $(0.2 \mathrm{~g} /$ dl) as well as urine monoclonal IgG $\kappa$ and free $\kappa$ light chains were detected (Table 2). A biopsy from the fracture site demonstrated a solid infiltrate of plasma cells (Figure 1a) that were positive for EBVencoded small RNA (EBER) by in situ hybridization. Plasma cell myeloma PTLD was diagnosed.

The fracture site was stabilized surgically, and local radiation was administered. The dose of cyclosporine was reduced initially, but was returned to its initial therapeutic level because the serum alkaline phosphatase level increased (to $852 \mathrm{U} / \mathrm{l}$ ),

Table 1 Clinical features

\begin{tabular}{|c|c|c|c|c|c|c|c|c|}
\hline Case & $\begin{array}{l}\text { Age/ } \\
\text { Sex }\end{array}$ & $D x$ & Allograft & IS & $\begin{array}{l}\text { Time to } \\
\text { PTLD }\end{array}$ & $T X$ & Response & Survival \\
\hline 1 & $67 / \mathrm{M}$ & $\begin{array}{l}\text { Cirrhosis, } \\
\text { hepatitis C }\end{array}$ & Liver & Cyclosporine & $2 y$ & ROI/radiation, surgery & CR & Alive ( $>5 \mathrm{y}$ ) \\
\hline 2 & $55 / F$ & $\begin{array}{l}\text { ESRD, LGN, } \\
\text { RCC }\end{array}$ & Kidney & Cyclosporine, mycoph. Mof. & $3 y$ & ROI/chemo, dexamethasone & PR & DOD (1 y) \\
\hline 3 & $61 / \mathrm{M}$ & ESRD, HTN & Kidney & Tacrolimus, dexamethasone & $20 \mathrm{~m}$ & ROI, dexamethasone & PR & Alive $(>4 \mathrm{~m})$ \\
\hline 4 & $46 / \mathrm{F}$ & IEM & $\begin{array}{l}\text { Small } \\
\text { bowel }\end{array}$ & Cyclosporine, tacrolimus & $1 \mathrm{y}$ & ROI & CR & Alive ( $>4 \mathrm{y}$ ) \\
\hline
\end{tabular}

Abbreviations: chemo, chemotherapy; CR, complete response; DOD, died of disease; Dx, diagnosis prior to transplantation; ESRD, end-stage renal disease; HTN, hypertension; IEM, idiopathic enteromyopathy; IS, immunosuppressor; LC, light chains; LGN, lupus glomerulonephritis; m, months; mycoph. mof., mycophenolate mofetil; PR, partial response; RCC, renal cell carcinoma; ROI, reduction of immunosuppression; Time to PTLD, time from transplant to diagnosis of PTLD; Tx, treatment of PTLD; y, years.

Table 2 Pathological features

\begin{tabular}{|c|c|c|c|c|c|c|}
\hline Case & $P T L D$ & $B M$ & Lytic lesion & EBER-ISH & Paraprotein & PTLD site \\
\hline 1 & PCM & + & + & + & $\begin{array}{l}\text { Serum: } \operatorname{IgG} \kappa 0.2 \mathrm{~g} / \mathrm{dl} \\
\text { Urine: } \operatorname{IgG} \kappa \text { and free } \kappa \mathrm{LC}\end{array}$ & Femur/BM \\
\hline 2 & PCM & + & + & + & $\begin{array}{l}\text { Serum: } \kappa \mathrm{LC} 0.81 \mathrm{~g} / \mathrm{dl} \\
\text { Urine: free } \kappa \mathrm{LC}\end{array}$ & Vertebra/BM \\
\hline 3 & PCM & + & + & - & $\begin{array}{l}\text { Serum: IgG } 2.99 \mathrm{~g} / \mathrm{dl} \\
\text { Urine: } \operatorname{IgG} \kappa \text {, free } \kappa \mathrm{LC}\end{array}$ & Skull/spine/BM \\
\hline 4 & $\begin{array}{l}\text { Polymorphic } \\
\text { PTLD }\end{array}$ & + & - & + & Serum: IgM $1.42 \mathrm{~g} / \mathrm{dl}$ & Liver/BM \\
\hline
\end{tabular}

Abbreviations: BM, bone marrow; EBV, Epstein-Barr virus; ISH, in situ hybridization; LC, light chain; PCM, plasma cell myeloma; PTLD, posttransplant lymphoproliferative disorders. 


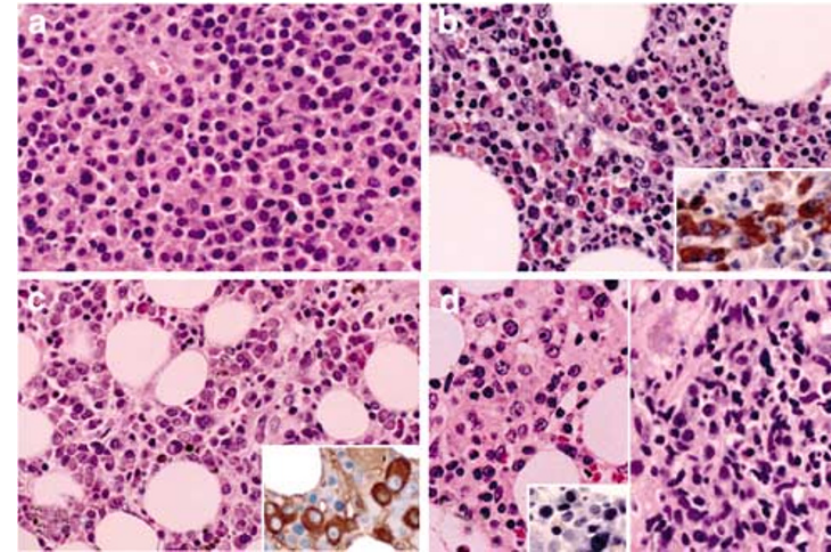

Figure 1 Biopsies demonstrating plasma cell infiltrates. (a) Bone fracture site of case 1 showing a solid infiltrate of plasma cells. (b) Bone marrow biopsy of case 2 demonstrating a plasma cell infiltrate (inset: $\kappa$ light-chain immunostaining). (c) Bone marrow biopsy of case 3 showing an extensive plasma cell infiltrate (inset: $\kappa$ light-chain immunostaining). (d) Biopsies of bone marrow (left) and liver (right) of case 4 showing polymorphic lymphoplasmacytic infiltrate (inset: EBER in situ hybridization of the bone marrow).

indicating hepatic dysfunction. The cyclosporine level was maintained at $150 \mathrm{mg}$ twice daily for 5 months until October 1996 when it was reduced to $125 \mathrm{mg}$ twice daily and ultimately to $100 \mathrm{mg}$ twice daily in February 1997, 9 months after PTLD diagnosis. Prednisone (5 mg daily) was continued without interruption. At 4 months after PTLD was diagnosed, the bone lesion had healed and the serum monoclonal protein was almost undetectable. At last follow-up, 5 years after the diagnosis of PTLD, the serum monoclonal protein was not detectable, bone pain was absent, and the allograft liver function tests were within the normal ranges.

\section{Case 2}

A 55-year-old woman with systemic lupus erythematosus-related glomerulonephritis and renal cell carcinoma developed end-stage renal disease. She received a living donor renal transplant in August 1996. Her immunosuppressive therapy was cyclosporine and mycophenolate mofetil (Table 1). In May 1999, 3 years after transplantation, she presented with fatigue and bone pain. X-ray revealed multiple lytic bone lesions in the calvarium and a compression fracture of the thoracic 7 th vertebra. A bone marrow biopsy showed a plasma cell infiltrate (Figure 1b) that was EBER positive by in situ hybridization. The plasma cells comprised approximately $30 \%$ of the hematopoietic elements and included many with prominent nucleoli. Protein electrophoresis showed monoclonal free $\kappa$ immunoglobulin light chains in the serum $(0.81 \mathrm{~g} / \mathrm{dl})$ and urine (Table 2). Plasma cell myeloma PTLD was diagnosed.

Cyclosporine was discontinued, and the patient was treated with dexamethasone. The bone pain
Myeloma and polymorphic PTLD in solid organ transplant recipients $\mathrm{X}$ Sun et al

improved, and the amount of the serum monoclonal protein declined. However, cyclosporine therapy was resumed 6 months after PTLD diagnosis because of signs of graft rejection. The amount of immunoglobulin light chain in the serum and urine dramatically increased, reaching $3 \mathrm{~g} / \mathrm{dl}$ in the urine by December 1999. Plasmaphoresis was instituted 3 times weekly initially, and then changed to daily treatments to remove the serum monoclonal protein. Renal function improved with the daily plasmaphoresis therapy. In January 2000, 8 months after the PTLD diagnosis, a repeat bone marrow biopsy that showed the plasma cell infiltrate had increased to comprise nearly $100 \%$ of the hematopoietic elements. Radiologic studies performed at the time of the repeat bone marrow biopsy showed multiple lytic bone lesions and compression fractures of the vertebrae. She received combination chemotherapy, and cyclosporine was discontinued. She died 1 year after the initial diagnosis of PTLD due to complications of PTLD.

\section{Case 3}

A 61-year-old man with renal failure, attributed to long-standing hypertension, received a living related donor renal transplant in May 2000. Immunosuppressive therapy included tacrolimus and dexamethasone. Routine allograft biopsies showed changes consistent with postinfectious glomerulonephritis. At 2 years after the transplant, January 2002, he presented with low-grade fever, nausea, malaise, and vague bone pain (Table 1). At admission, laboratory studies showed anemia (hemoglobin $8.6 \mathrm{~g} / \mathrm{dl}$ ), leukopenia (white blood cell count $2400 / \mu \mathrm{l})$, and increased serum creatinine $(5.1 \mathrm{mg} / \mathrm{dl})$ consistent with allograft dysfunction. Surveillance $\mathrm{X}$-rays showed several lytic bone lesions in the skull and spine. A bone marrow biopsy showed an extensive, plasma cell infiltrate (Figure 1c). The plasma cells were large, with prominent nucleoli, and were EBER negative by in situ hybridization. An ERER positive control tissue was appropriately positive. Serum protein electrophoresis showed an IgG $\kappa$ monoclonal protein $(2.99 \mathrm{~g} / \mathrm{dl})$ with free $\kappa$ immunoglobulin light chains in the urine (Table 2). Plasma cell myeloma PTLD was diagnosed.

Repeat biopsy of the allograft kidney revealed changes consistent with postinfectious glomerulonephritis and absence of immunoglobulin deposition by immunofluorescence microscopy. Owing to poor allograft function and the presence of PTLD, tacrolimus was discontinued and hemodialysis resumed. Treatment with dexamethasone was initiated, and at 4 months follow-up, the serum monoclonal protein had decreased to $2.3 \mathrm{~g} / \mathrm{dl}$.

\section{Case 4}

A 46-year-old woman received a small bowel transplant for idiopathic enteromyopathy and 
received cyclosporine and tacrolimus immunosuppressive therapy. At 1 year after the allograft transplantation (November 1997), she presented with fever, nausea, vomiting, abdominal pain, and increased serum liver enzyme levels (Gamma glutamyl transferase 628 unit/l, alkaline phosphatase $822 \mathrm{unit} / \mathrm{l}$, and lactate dehydrogenase $286 \mathrm{mg} / \mathrm{dl}$ ) (Table 1). Computed tomography scan showed heptosplenomegaly and widespread mesenteric lymphadenopathy. A bone marrow biopsy revealed multiple focal, random lymphoplasmacytic infiltrates composed of a mixture of small matureappearing lymphocytes, medium-size lymphocytes with slightly irregular nuclei, lymphoplasmacytoid cells, and plasma cells. The infiltrates had irregular margins that extended into the surrounding normal bone marrow (Figure 1d left), comprised $20 \%$ of the bone marrow elements, and were positive for EBER by in situ hybridization. A liver biopsy demonstrated a dense lymphoplasmacytic infiltrate in the portal tracts (Figure 1d right). Serum protein electrophoresis demonstrated monoclonal IgM $\lambda$ protein (IgM $1.42 \mathrm{~g} / \mathrm{dl})$. Both the bone marrow and liver biopsies were diagnosed as polymorphic PTLD closely resembling a lymphoplasmacytic lymphoma (LPL) (Table 2).

Immunosuppressive therapy was discontinued, graft function improved dramatically, and serum liver enzyme levels returned to normal limits within 1 week following PTLD diagnosis. Immunosuppressive therapy was reinstituted 3 weeks following PTLD diagnosed. Although she experienced several episodes of graft rejection (attributed to poor absorption of the immunosuppressive agents), she is alive with no evidence of PTLD at 4 years after the initial diagnosis.

\section{Discussion}

Although PTLD with plasmacytic differentiation are common, ${ }^{8}$ plasma cell myeloma PTLD in solid organ transplant recipients is rare. ${ }^{22}$ The three patients with plasma cell myeloma PTLD we report all presented within 20 months to 3 years after receiving solid organ transplants (one liver and two kidneys) with clinical, radiologic, and pathologic features typical of plasma cell myeloma. Each had bone pain associated with lytic bone lesions, serum and urine monoclonal proteins, and bone marrow plasma cell infiltrates. The percent of bone marrow plasmacytosis varied from 30 to $100 \%$ of the hematopoietic elements during the course of the disease.

We were able to identify 18 case reports of plasma cell myeloma PTLD in the literature. Eight patients had lytic bone lesions. Four of the eight also had bone marrow plasma cell infiltrates with serum or urine monoclonal proteins similar to our three cases. ${ }^{23-26}$ The remaining four cases either lacked serum or urine monoclonal protein or bone marrow plasma cell infiltrates, or the reports did not provide these data. ${ }^{10,20,27,28}$ At least one case ${ }^{20}$ without a bone marrow plasma cell infiltrate had findings that were otherwise characteristic for plasma cell myeloma.

Plasma cell myeloma in the nontransplant setting typically presents with bone marrow-based, multifocal plasma cell proliferations that are associated with lytic bone lesions and serum or urine monoclonal proteins. ${ }^{29}$ In the absence of these typical findings, diagnosing plasma cell myeloma in the post-transplant setting is problematic since other histologic types of PTLD share some clinical, laboratory, and pathologic features of plasma cell myeloma PTLD. For instance, nonplasma cell myeloma PTLDs involve multiple anatomic sites in more than $50 \%$ of cases, are extranodal in about $70 \%$ of cases, $^{9}$ commonly display plasmacytic differentiation, ${ }^{8}$ are frequently associated with small serum monoclonal proteins, and can involve the bone marrow. ${ }^{6}$ We classified these three cases as plasma cell myeloma PTLD because they showed all the clinical, laboratory, and radiologic features of plasma cell myeloma, as defined in the nontransplant setting. Each patient had lytic bone lesions, bone marrow plasma cells infiltrate, and serum monoclonal protein.

The polymorphic PTLD (case 4) with a lymphoplasmacytic infiltrate and a serum monoclonal IgM protein was indistinguishable from a LPL. Polymorphic PTLDs frequently show plasmacytic differentiation similar to a LPL, and are associated with serum and/or urine monoclonal proteins in up to $66 \%$ cases. $^{30}$ In addition, bone marrow involvement by PTLD, including those with plasmacytic differentiation, is not uncommon. ${ }^{31,32}$

Three of the four PTLD cases in our series, including the polymorphic PTLD, were EBV positive. One case was EBER-in situ hybridization negative. The possibility that this EBV-negative PTLD may represent a coincidental, conventional plasma cell myeloma cannot be completely excluded, although one of the 18 previously reported cases of plasma cell myeloma PTLD was also EBV negative; this EBV negative case was evaluated by both EBER in situ hybridization and polymerase chain reaction. ${ }^{20}$ Three previously reported plasma cell myeloma PTLD were EBV positive, ${ }^{21,26,33}$ and EBV status was not reported in the remaining 14 cases (Table 3).

Two patients with plasma cell myeloma PTLD (cases 1 and 3) in our series showed complete response to a reduction of immunosuppression, and one died of PTLD complications. Therapy and the response to therapy varied in the 18 previously reported plasma cell myeloma PTLD; two resolved completely: one with chemotherapy, and the other with a reduction of immunosuppression. ${ }^{23,34}$ Three cases showed partial response, and all were treated with chemotherapy. ${ }^{10,20,26}$ Seven showed no 
Table 3 Summary of reported cases of PCM and polymorphic PTLD with serum paraprotein

\begin{tabular}{|c|c|c|c|c|c|c|c|c|c|}
\hline Age/sex & Time $^{a}$ & Serum paraprotein & $B M$ & $T \times$ of $P T L D$ & $\operatorname{Resp}$ & $E B V$ & Survival & Allograft & $\operatorname{Ref}$ \\
\hline $67 / \mathrm{M}$ & 2 years & $\mathrm{IgG} \kappa 0.2 \mathrm{~g} / \mathrm{dl}$ & $+{ }^{\mathrm{b}}$ & $\mathrm{ROI} / \mathrm{rad}$ & CR & Pos & Alive ( $>5$ years) & Liver & Sun \\
\hline $55 / \mathrm{F}$ & 3 years & $\kappa \mathrm{LC} 0.81 \mathrm{~g} / \mathrm{dl}$ & + & ROI & PR & Pos & 1 year & Kidney & Sun \\
\hline 61/M & 1 year 8 months & $\mathrm{IgG} \kappa 1.85 \mathrm{~g} / \mathrm{dl}$ & + & ROI & PR & Neg & Alive ( $>2$ months) & Kidney & Sun \\
\hline $46 / \mathrm{F}$ & 1 year & $\mathrm{IgM} 1.42 \mathrm{~g} / \mathrm{dl}$ & + & ROI & CR & Pos & Alive ( $>4$ years) & Small b & Sun \\
\hline 39/M & 4 years & $\operatorname{IgA} \kappa(0.73 \mathrm{~g} / \mathrm{dl})$ & + & NA & NA & NA & 3 days & Kidney & 38 \\
\hline $54 / F$ & 3 years & $\kappa \mathrm{LC}(1.9 \mathrm{~g} / 24 \mathrm{~h})$ & + & Cyph/P & No & NA & 6 months & Kidney & 35 \\
\hline $55 / F$ & 5 years & $\operatorname{IgG}$ & + & Chemo & CR & NA & Alive & Kidney & 23 \\
\hline $4 / \mathrm{M}$ & 12 years & $\operatorname{IgG}(3.15 \mathrm{~g} / \mathrm{dl})$ & + & NA & NA & NA & 4 months & Kidney & 39 \\
\hline NA/NA & 2 years & NA & + & Chemo & PR & NA & Alive & Heart & 10 \\
\hline NA/NA & 3.5 years & NA & + & ROI & No & NA & 1month & Heart & 10 \\
\hline $55 / F$ & 4 years & Neg & + & $C A V$ & No & NA & 2 months & Kidney & 27 \\
\hline $62 / \mathrm{M}$ & 15 years & $\operatorname{IgG} \kappa(5.4 \mathrm{~g} / \mathrm{dl})$ & + & None & Stable & NA & Alive ( $>12$ months) & Kidney & 37 \\
\hline $53 / \mathrm{M}$ & 2 years & $\operatorname{Ig} A \lambda$ & + & NA & NA & NA & 1 month & Heart & 40 \\
\hline $51 / \mathrm{F}$ & $<2 \mathrm{~m}$ & IgG $\kappa / \lambda$ (biclonal) & + & ROI & CR & NA & Alive ( $>18$ months) & Kidney & 34 \\
\hline $48 / \mathrm{F}$ & 1.5 years & $\lambda \mathrm{LC}(0.98 \mathrm{~g} / 24 \mathrm{~h})$ & - & ROI/chemo/rad & PR & Neg & 11 months & Heart & 20 \\
\hline $57 / \mathrm{M}$ & 2 years & $\operatorname{IgG} \kappa(1.7 \mathrm{~g} / \mathrm{dl})$ & + & $V A D$ & No & NA & 4 months & Heart & 24 \\
\hline 61/M & 5years $\mathrm{h}, 2$ years $\mathrm{k}$ & $\operatorname{Ig} A \lambda$ & + & CHOP & No & NA & Short & $\mathrm{H}$ and $\mathrm{K}$ & 36 \\
\hline 56/M & 6 years & $\operatorname{IgG} \kappa$ & NA & rad/chemo & NA & NA & 6 months & Heart & 28 \\
\hline $63 / \mathrm{F}$ & 1.5 years & NA & NA & ROI/chemo/rad & No & NA & 2 months & Heart & 21,29 \\
\hline 68/M & 1.5 years & NA & + & ROI/chemo & No & NA & $<1$ month & Heart & 21,29 \\
\hline 38/M & 7 years & $\operatorname{IgA} \lambda 1.8 \mathrm{~g} / \mathrm{dl}$ donor & + & $V A D$ & NA & NA & 3 months & Kidney & 25 \\
\hline $47 / \mathrm{M}$ & 8 years & $\operatorname{IgG} \kappa$ & + & ROI/CNOP/ra & PR & Pos & Alive & Kidney & 26 \\
\hline
\end{tabular}

Time from transplant to diagnosis.

b +: involved, -: not involved.Abbreviations: BM, bone marrow involvement; $C A V$, cyclophosphomide, adriamycin, and vincristine; chemo, chemotherapy, type not specified; CHOP, cyclophosphamide, doxorubicin, vincristin and prednisolone; CNOP, cyclophosphamide, mitoxantrone, vincristin and prednisone; CR, complete response; Cyph, cyclophosphamide; EBV, Epstein-Barr virus; h, heart; k, kidney; LC, light chains; $\mathrm{m}$, months of survival; NA, not available; Neg, negative; P, prednisone; pos, positive; PR, partial response; rad, radiation therapy; Ref, reference; Resp, response to therapy; ROI, reduction of immunosuppression; Small b, small bowel; Tx, treatment; VAD, vincristine, doxorubicin, dexamethasone.

response, and all but one received chemotherapy. ${ }^{10,24,27,29,35,36}$ The one nonresponder who did not receive chemotherapy was treated with only a reduction of immunosuppression. ${ }^{10}$ One patient had stable disease, despite a lack of reduction of immunosuppression or treatment with chemotherapy. ${ }^{37}$ Information regarding responses to treatment was not available for the remaining five patients. Thus a subset of plasma cell myeloma PTLD responds to a reduction of immunosuppression while others do not, a finding not dissimilar to the other morphologic types of PTLD. ${ }^{8}$

In summary, we report three plasma cell PTLD cases and one case of polymorphic, PTLD with monoclonal serum protein. All three plasma cell myeloma PTLD had clinical, radiologic, and pathologic features of conventional plasma cell myeloma. The polymorphic PTLD was associated with an IgM serum monoclonal protein and closely resemble a LPL. One patient died of PTLD, the remaining three are alive: two are completely free of PTLD, and one has shown a partial response to therapy.

\section{Acknowledgements}

We thank Chris Yeager, Editorial Assistant, at Department of Scientific Publications of The University of Texas MD Anderson Cancer Center for his critical editorial comments on the manuscript.

\section{References}

1 Nelson BP, Nalesnik MA, Bahler DW, et al. EpsteinBarr virus-negative post-transplant lymphoproliferative disorders: a distinct entity? Am J Surg Pathol 2000;24:375-385.

2 Leblond V, Davi F, Charlotte F, et al. Posttransplant lymphoproliferative disorders not associated with Epstein-Barr virus: a distinct entity? J Clin Oncol 1998;16:2052-2059.

3 Nalesnik MA. Clinicopathologic characteristics of post-transplant lymphoproliferative disorders. Recent Results Cancer Res 2002;159:9-18.

4 Finn L, Reyes J, Bueno J, et al. Epstein-Barr virus infections in children after transplantation of the small intestine. Am J Surg Pathol 1998;22:299-309.

5 Ho M, Miller G, Atchison RW, et al. Epstein-Barr virus infections and DNA hybridization studies in posttransplantation lymphoma and lymphoproliferative lesions: the role of primary infection. J Infect Dis 1985;152:876-886.

6 Frizzera G. Atypical lymphoproliferative disorders. Knowles DM (ed). Neoplastic Hematopathology, 2nd ed. Lippincott Williams \& Wilkins: Philadelphia, Baltimore, New York, London, Buenos Aires, Hong Kong, Sydney, Tokyo, 2001.

7 Leblond V, Sutton L, Dorent R, et al. Lymphoproliferative disorders after organ transplantation: a report of 24 cases observed in a single center. J Clin Oncol 1995;13:961-968.

8 Nalesnik MA, Jaffe R, Starzl TE, et al. The pathology of posttransplant lymphoproliferative disorders occurring in the setting of cyclosporine A-prednisone 
immunosuppression. Am J Pathol 1988;133: 173-192.

9 Penn I. The problem of cancer in organ transplant recipients: an overview. Transplant Sci 1994;4:23-32.

10 Armitage JM, Kormos RL, Stuart RS, et al. Posttransplant lymphoproliferative disease in thoracic organ transplant patients: ten years of cyclosporine-based immunosuppression. J Heart Lung Transplant 1991;10:877-86; discussion 886-887.

11 Curtis RE, Travis LB, Rowlings PA, et al. Risk of lymphoproliferative disorders after bone marrow transplantation: a multi-institutional study. Blood 1999;94:2208-2216.

12 Kowal-Vern A, Swinnen L, Pyle J, et al. Characterization of postcardiac transplant lymphomas. Histology, immunophenotyping, immunohistochemistry, and gene rearrangement. Arch Pathol Lab Med 1996;120:41-48.

13 Yousem SA, Randhawa P, Locker J, et al. Posttransplant lymphoproliferative disorders in heart-lung transplant recipients: primary presentation in the allograft. Hum Pathol 1989;20:361-369.

14 Starzl TE, Nalesnik MA, Porter KA, et al. Reversibility of lymphomas and lymphoproliferative lesions developing under cyclosporin-steroid therapy. Lancet 1984;1:583-587.

15 Ferry JA, Jacobson JO, Conti D, et al. Lymphoproliferative disorders and hematologic malignancies following organ transplantation. Mod Pathol 1989;2: 583-592.

16 Radl J, Valentijn RM, Haaijman JJ, et al. Monoclonal gammapathies in patients undergoing immunosuppressive treatment after renal transplantation. Clin Immunol Immunopathol 1985;37:98-102.

17 Sheil AGR, Flavel S, Disney APS, et al. Cancer in Dialysis and Transplant Patients. Transplant Proc 1985;17:195-198.

18 Penn I. Cancer and Transplantation. Marcel Dekker: New York, 1987.

19 Sheil AG, Flavel S, Disney AP, et al. Cancer incidence in renal transplant patients treated with azathioprine or cyclosporine. Transplant Proc 1987;19:2214-2216.

20 Chucrallah AE, Crow MK, Rice LE, et al. Multiple myeloma after cardiac transplantation: an unusual form of posttransplant lymphoproliferative disorder. Hum Pathol 1994;25:541-545.

21 Knowles DM, Cesarman E, Chadburn A, et al. Correlative morphologic and molecular genetic analysis demonstrates three distinct categories of posttransplantation lymphoproliferative disorders. Blood 1995;85:552-565.

22 Swerdlow SH. Classification of the posttransplant lymphoproliferative disorders: from the past to the present. Semin Diagn Pathol 1997;14:2-7.

23 Berthelemy C, Mourad G, Bataille R, et al. Occurrence of multiple myeloma 5 years after renal transplantation. Presse Med 1988;17:1706.

24 Fischer T, Miller M, Bott-Silverman C, et al. Posttransplant lymphoproliferative disease after cardiac transplantation. Two unusual variants with predominantly plasmacytoid features. Transplantation 1996;62:1687-1690.

25 Grey M, Townsend N, Lappin D, et al. IgA myeloma of donor origin arising 7 years after allogeneic renal transplant. Br J Haematol 2000;108:592-594.
26 Ancin I, Sarra J, Peris J, et al. Demonstration of Epstein-Barr virus in a case of multiple myeloma after renal transplantation. Haematologica 2000;85: 773-774.

27 Bowen PA, Caruana RJ. A secretory myeloma in a renal-transplant recipient. Clin Transplant 1991;5: 408-410.

28 Leigh BR, Larkin EC, Doggett RLS. Solitary extramedullary plasmacytoma five years after successful cardiac transplantation. Am J Clin Oncol 1997;20: $467-470$.

29 Grogan TM, Van Camp B, Kyle RA, et al. Plasma cell neoplasms. In: Jaffe ES, Harris NL, Stein H, Vardiman JW (eds). Pathology and Genetics. Tumours of Haematopoietic and Lymphoid Tissues. World Health Organization Claassification of Tumours. IARC Press: Lyon, France, 2001.

30 Badley AD, Portela DF, Patel R, et al. Development of monoclonal gammopathy precedes the development of Epstein-Barr virus-induced posttransplant lymphoproliferative disorder. Liver Transplant Surg 1996;2: 375-382.

31 Hanto DW, Frizzera G, Purtilo DT, et al. Clinical spectrum of lymphoproliferative disorders in renal transplant recipients and evidence for the role of Epstein-Barr virus. Cancer Res 1981;41:4253-4261.

32 Nelson BP, Locker J, Nalesnik MA, et al. Clonal and morphological variation in a posttransplant lymphoproliferative disorder: evolution from clonal T-cell to clonal B-cell predominance. Hum Pathol 1998;29: 416-421.

33 Chadburn A, Chen JM, Hsu DT, et al. The morphologic and molecular genetic categories of posttransplantation lymphoproliferative disorders are clinically relevant. Cancer 1998;82:1978-1987.

34 Passweg J, Bock HA, Tichelli A, et al. Transient multiple myeloma' after intense immunosuppression in a renal transplant patient. Nephrol Dialysis Transplant 1993;8:1393-1394.

35 Howard AD, Moore J, Tomaszewski MM. Occurrence of multiple myeloma three years after successful renal transplantation. Am J Kidney Dis 1987;10: 147-150.

36 Haas M, Mannhalter C, Ullrich R, et al. A multilocular B-cell neoplasia presenting as multiple myeloma and polymorphic lymphoma of recipient origin 2 months after kidney transplantation in a heart-transplant recipient. Nephrol Dialysis Transplant 1996;11: 2085-2087.

37 Brown JH, Newstead CG, Jos V, et al. Multiple myeloma in a renal transplant recipient. Nephrol Dialysis Transplant 1992;7:447-449.

38 Melato M, Paladini G. Multiple myeloma following reactivated Epstein-Barr virus infection in a renaltransplant recipient. Haematologica 1986;71: 241-243.

39 Aparicio M, de Precigout V, Reiffers J, et al. Multiple myeloma and AL amyloidosis in a renal transplant recipient. Nephron 1989;53:373-375.

40 Guerci AP, Burtin P, Mattei S, et al. Lymphoproliferative syndromes after cardiac transplantation and treatment with cyclosporine. Report of 4 cases. Ann Med Interne 1992;143:155-159. 